\title{
New liquid-free proton conductive nanocomposite based on imidazole-functionalized cellulose nanofibers
}

\author{
Iga Aleksandra Jankowska (1D) Katarzyna Pogorzelec-Glaser $(\mathbb{D} \cdot$ \\ Paweł Lawniczak • Michał Matczak • Radosław Pankiewicz
}

Received: 5 June 2020/ Accepted: 12 November 2020/Published online: 2 December 2020

(C) The Author(s) 2020

\begin{abstract}
The first successful attempt to synthesize a new proton conducting polymeric nanocomposite film based on pure cellulose nanofibers (CNF) as a polymer matrix functionalized on their surface with imidazole molecules (Im) as a dopant, was made. The 2CNF-Im nanomaterial contains on average one molecule of imidazole per 2 glucose units from cellulose chains. Water evaporation and thermal stability of 2CNF-Im were studied by thermogravimetric analysis (TGA and DTG) and differential scanning calorimetry (DSC). The temperature dependence of electrical conductivity
\end{abstract}

I. A. Jankowska $(\bowtie) \cdot$ K. Pogorzelec-Glaser $(\bowtie)$. P. Ławniczak

Institute of Molecular Physics, Polish Academy of

Sciences, M. Smoluchowskiego 17, 60-179 Poznań,

Poland

e-mail: iga@ifmpan.poznan.pl;

iga.a.jankowska@gmail.com

K. Pogorzelec-Glaser

e-mail: kglaser@ifmpan.poznan.pl

P. Ławniczak

e-mail: pawel.lawniczak@ifmpan.poznan.pl

M. Matczak

Faculty of Physics, University of Białystok,

Ciołkowskiego 1L, 15-245 Białystok, Poland

e-mail: m.matczak@uwb.edu.pl

\section{R. Pankiewicz}

Faculty of Chemistry, Adam Mickiewicz University, Umultowska 89b, 61-614 Poznań, Poland

e-mail: radek@px.pl was studied by the impedance spectroscopy. At $140{ }^{\circ} \mathrm{C}$, the $2 \mathrm{CNF}-\mathrm{Im}$ nanocomposite has a maximum conductivity of $7.0 \times 10^{-3} \mathrm{~S} / \mathrm{m}$, i.e. four orders of magnitude higher than that of non-functionalized CNF matrix. The newly synthesized cellulose nanocomposite exhibits high electrical and thermal stability. In 2CNF-Im, the activation energy of the proton transport process is the lowest compared to the previously synthesized imidazole-functionalized composites based on other pure cellulose materials and equals $0.62 \mathrm{eV}$. The synthesized nanomaterial is liquid-free solid polymer electrolyte showing proton conductivity above the boiling point of water.

Keywords Polymer-matrix nanocomposite . Cellulose nanofibers · Imidazole $\cdot$ Proton conductivity $\cdot$ Thermal properties

\section{Introduction}

It is still a challenge to obtain solid-state protonconducting polymer electrolytes showing properties making them attractive for application in electrochemical devices, e.g., batteries, fuel cells. Such materials should show the proton conductivity above the boiling point of water, should be liquid-free, thermally stable, environmentally friendly, and easy to manufacture. Currently, the most commonly used polymeric material to fabricate proton exchange 
membranes (PEMs) is Nafion. Nafion in the hydrated state shows high proton conductivity values $(>10 \mathrm{~S} /$ $\mathrm{m})$, but its operating temperature range is below the boiling point of water. Additionally, Nafion is complicated to manufacture and relatively expensive, about $1700 \$ / \mathrm{m}^{2}$ (Bayer et al. 2016; Liu et al. 2018; Hernández-Flores et al. 2016; Mizera et al. 2019; Tiwari et al. 2016; Wong et al. 2019). In the search for new solid polymer electrolytes, an interesting approach is to modify natural polymers (Fujishima et al. 2008; Hernández-Flores et al. 2016; Jesuraj and Manimuthu 2018; Kalaiselvimary and Prabhu 2018; Kalaiselvimary et al. 2019; Połomska et al. 2010, 2011; Yamada and Goto 2012; Yamada and Ogino 2015), including the most abundant polymer in nature and the main building material of plants cellulose. Many different types of cellulose have investigated in polymeric proton-conducting electrolytes: bacterial cellulose (Gadim et al. 2016; Jiang et al. 2012; Vilela et al. 2020), cellulose whiskers (Xu et al. 2019), cellulose nanocrystals (Bano et al. 2019; Bayer et al. 2016; Ni et al. 2016, 2018; Zhao et al. 2019a), and cellulose nanofibers (CNF) (Bayer et al. 2016; Di and Yin 2019; Cai et al. 2018; Gu et al. 2019; Guccini et al. 2019; Xu et al. 2018; Zhao et al. 2019b). Among these reports, some research concerns the incorporation of $\mathrm{CNF}$ into sulfonated poly(ether sulfone) (SPES) (Cai et al. 2018; Zhao et al. 2019a, b; Xu et al. 2018). Di and Yin (2019) introduce cellulose acetate nanofibers in imidazole solution into the SPES polymer matrix to obtain hybrid PEM with a maximum conductivity of $1.2 \times 10 \mathrm{~S} / \mathrm{m}$ at $80{ }^{\circ} \mathrm{C}$ under $100 \%$ humidity. However, proton-conducting polymer electrolytes based on different types of cellulose are not liquid-free and contain water. The presence of liquid water limits the operating temperature range of these materials. All the listed materials show high proton conductivity above $90 \%$ relative humidity $(\mathrm{RH})$ and have a maximum proton conductivity below the boiling point of water, e.g., $1.4 \times 10 \mathrm{~S} / \mathrm{m}$ at $94{ }^{\circ} \mathrm{C}$ (Gadim et al. 2016), $1.1 \times 10 \mathrm{~S} / \mathrm{m}$ at $80^{\circ} \mathrm{C}$ (Jiang et al. 2012), $1.6 \times 10^{-1} \mathrm{~S} / \mathrm{m}$ at $94{ }^{\circ} \mathrm{C}$ (Vilela et al. 2020), $2.0 \times 10 \mathrm{~S} / \mathrm{m}$ at $80{ }^{\circ} \mathrm{C}(\mathrm{Xu}$ et al. 2019$), 1.8 \times 10 \mathrm{~S} /$ $\mathrm{m}$ at $95{ }^{\circ} \mathrm{C}$ (Bano et al. 2019), $2.5 \times 10 \mathrm{~S} / \mathrm{m}$ at $90{ }^{\circ} \mathrm{C}$ (Ni et al. 2018), $1.5 \times 10 \mathrm{~S} / \mathrm{m}$ at $80^{\circ} \mathrm{C}$ (Cai et al. 2018), $1.3 \times 10 \mathrm{~S} / \mathrm{m}$ at $80^{\circ} \mathrm{C}$ (Xu et al. 2018), $2.6 \times 10 \mathrm{~S} / \mathrm{m}$ at $80{ }^{\circ} \mathrm{C}$ (Zhao et al. 2019b). Only Bayer et al. (2016) reports results for hydrated (100\%
RH) membranes at a higher temperature, but only up to $120{ }^{\circ} \mathrm{C}$ : for cellulose nanocrystals a maximum conductivity equals $4.6 \times 10^{-1} \mathrm{~S} / \mathrm{m}$ at $120^{\circ} \mathrm{C}$, and for $\mathrm{CNF}$ is equal to $5.0 \times 10^{-3} \mathrm{~S} / \mathrm{m}$ at $100{ }^{\circ} \mathrm{C}$.

The surface modification of cellulose materials may allow obtaining green energy materials. The replacement of liquid water by heterocyclic molecules as conducting dopant allows to increase the maximum of conductivity at above $100{ }^{\circ} \mathrm{C}$ and to obtain liquid-free polymer electrolytes. Cellulose materials can be divided, among others by their structure on a dimensional scale into: microcrystalline cellulose (CMC), nanocrystalline cellulose (CNC), cellulose microfibers (CMF), and CNF. Our group synthesized several anhydrous composites based on pure celluloses (CMC, $\mathrm{CNC}, \mathrm{CMF}$ ) functionalized with imidazole (Im), exhibit proton conductivity above the boiling point of water (Jankowska et al. 2020; Smolarkiewicz et al. 2015, 2016; Tritt-Goc et al. 2018, 2019). Previously reported results (Jankowska et al. 2018) allowed us to hypothesize that the functionalization of CNF with imidazole should be more effective and result in the higher conductivity values and the lower activation energy of the proton transport process in comparison to composites based on other cellulose materials. Thermal and conduction properties of pure cellulose matrix are the most important features determining the properties of composite material. Compared to other cellulose materials, CNF are characterized by the higher thermal stability and the lower activation energy of the proton transport process (Jankowska et al. 2018). The activation energy of the proton transport process in CMC-based composite, 5.4CMCIm (one imidazole molecule per 5.4 glucose units) is equal to $0.82 \mathrm{eV}$ (Smolarkiewicz et al. 2015, 2016). In CMF-based composite (1 imidazole molecule per 3.5 glucose units), the activation energy is $0.95 \mathrm{eV}$ (Jankowska et al. 2020). In 1.3CNC-Im composite, the activation energy equals $0.78 \mathrm{eV}$ (Tritt-Goc et al. 2019). The imidazole content in 2CNF-Im is not significant. However, the results described in this paper show that the 2CNF-Im nanocomposite exhibits the lowest value of activation energy $(0.62 \mathrm{eV})$ in comparison to other imidazole-functionalized composites based on pure cellulose materials. Moreover, thanks to the use of CNF to synthesize of composite, it was possible to increase the imidazole concentration in 2CNF-Im in comparison with the 3.5CMF-Im composite. In contrast to the CMF-based composite, it 
was possible to obtain the nanocomposite in the form of a film.

The structure of cellulose fibers is stabilized by a network of hydrogen bonds between hydroxyl groups, which determine the reactivity and physical properties of cellulose materials. The monomer of cellulose is composed of two molecules of $\beta$-D-glucopyranose connected by a $\beta-1-4$ linkage, and each glucose residue has three $\mathrm{OH}$ groups. $\mathrm{CNF}$ are nanoscale cellulose fibers with lateral dimensions up to $100 \mathrm{~nm}$ and microscale lengths. CNF are odorless, white, characterized by high strength and stiffness, ecofriendly and fully renewable, exhibit high mechanical resistance, and relative thermal stability, being also a low-cost nanomaterial (Sofla et al. 2016; Sulaiman et al. 2015; Xu et al. 2013).

In comparison to cellulose materials in the microscale, CNF have a larger number of functional hydroxyl groups on the surface due to a higher surface area to volume ratio, which improves the modification effectiveness (Sulaiman et al. 2015). The use of CNF can allow increasing the concentration of heterocycles in synthesized composites and thus increase the conductivity and reduce the activation energy of the proton transport process. The imidazole molecules are heterocycles showing high thermal stability (the melting point of imidazole is $90{ }^{\circ} \mathrm{C}$, and the boiling point is $257^{\circ} \mathrm{C}$ ), amphoteric character, and a high degree of self-dissociation (Bhatnagar et al. 2011; Widelicka et al. 2017; Zięba et al. 2019). Imidazole can be immobilized in a polymeric material, but retain the ability of local dynamics, reorientation, dissociation, and tautomerization (Zhao et al. 2016). These mechanisms contribute to the proton conductivity in imidazole-functionalized liquid-free electrolytes above $100{ }^{\circ} \mathrm{C}$.

In this paper, we present the first results of the synthesis and characterization of new conductive nanomaterials based on pure CNF functionalized on the surface with imidazole. The first attempt to synthesize the new polymeric nanocomposite film was successful. The obtained $2 \mathrm{CNF}-\mathrm{Im}$ nanocomposite contains 1 molecule of imidazole per 2 glucose units from cellulose chains on average. 2CNF-Im samples were examined by elemental analysis, scanning electron microscopy (SEM), thermogravimetric analysis (TGA), differential scanning calorimetry (DSC), and electrical impedance spectroscopy (EIS) to establish their thermal and electrical properties. The results obtained for the newly synthesized nanocomposite were compared with those for pure CNF.

\section{Experimental section}

Materials

Pure CNF were provided by the University of Maine, USA, in the form of a stable suspension of nanofibers in deionized water in a concentration of $3.0 \% \mathrm{w} / \mathrm{w}$ (Fig. 1a). The suspension had a gel consistency. According to the manufacturer's specifications, CNF were obtained by mechanical treatment from wood pulp, therefore they do not contain acid groups, sulfur, chlorates, and nitrogen. The diameter of the fibers is about $50 \mathrm{~nm}$, and the fiber length is up to approximately $220 \mu \mathrm{m}$, the crystallinity index of $\mathrm{CNF}$ is $67-88 \%$, and decomposition temperature: $>349{ }^{\circ} \mathrm{C}$. The X-ray diffraction patterns of CNF film showed that the studied material belongs to cellulose I $\beta$ crystalline structure (Jankowska et al. 2018). The high purity polycrystalline imidazole (Im) was purchased from Sigma Aldrich Company.

Synthesis of 2CNF-Im film

Cellulose is insoluble in most solvents and forms only a suspension. CNF in the form of a hydrogel did not dissolve during the synthesis. A portion of CNF suspension $(66.7 \mathrm{~g}, 2.0 \mathrm{~g}$ dry mass) was diluted in water $(38 \mathrm{~mL})$ on stirring with a fast rotating magnetic stirrer with a triangle-shaped magnetic bar, at $25^{\circ} \mathrm{C}$ for $60 \mathrm{~min}$. Then, $20 \mathrm{~mL}$ of water solution of imidazole was added and the whole contents were subjected to vigorous stirring for $2 \mathrm{~h}$ and ultra-sonicated for

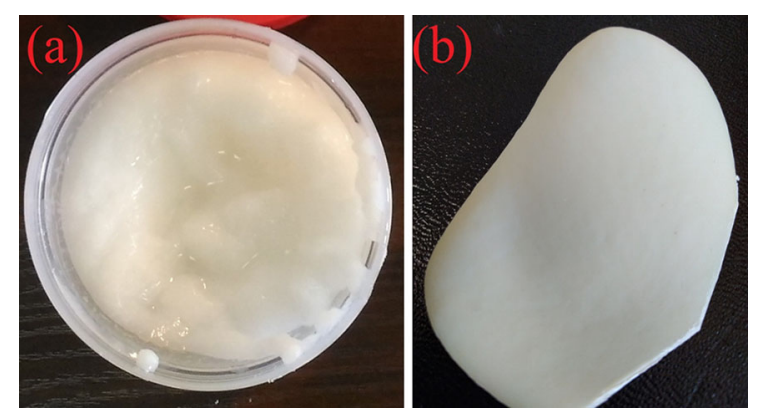

Fig. 1 Photograph of CNF hydrogel in a concentration of 3.0\% w/w (a), and prepared 2CNF-Im nanocomposite film (b) 
$15 \mathrm{~min}$. The rotations were regulated during the mixing process (150-450 RPM). The ultra-sonication power was $400 \mathrm{~W}$, and the frequency was equal to $40 \mathrm{kHz}$. Then stirring was continued for $48 \mathrm{~h}$ under reduced pressure to remove dissolved gases. After degassing, the white turbid suspension was moved to the PTFE Petri dish and dried under reduced pressure for 10 days. The final nanocomposite was in the form of a white film of the thickness close to $0.4 \mathrm{~mm}$ (Fig. 1b). The preparation of the pure CNF film is reported in Jankowska et al. (2018).

\section{Characterization methods}

The chemical composition of the synthesized 2CNFIm nanocomposite was verified using a Vario EL III Elemental Analyzer, GmbH Germany. Measurements were repeated three times and the results differed by less than $0.2 \%$. SEM images were obtained at room temperature (a Fei NovaSEM 650 microscope; in pressure $<6 \times 10^{-4} \mathrm{~Pa}$ ). The sample was adhered to the sample holder with a vacuum-operated carbon tape. Before putting it into the chamber, the sample was purged with ultra-pure nitrogen, it was not covered with any additional conductive layer.

Thermal properties of the newly synthesized 2CNF-Im nanocomposite and CNF, with particular emphasis on dehydration and decomposition processes, were determined using TGA (a Perkin-Elmer TGA 8000; from room temperature to $650{ }^{\circ} \mathrm{C}$ ) and DSC (a Perkin-Elmer DSC 4000). Thermograms were obtained by both techniques at a heating rate of $10{ }^{\circ} \mathrm{C} /$ min under nitrogen atmosphere. The DSC tests were conducted in closed pans with a small hole punctured at the top. The DSC measurements were carried out in two heating steps for both materials. At first, the samples were heated from 10 to $110{ }^{\circ} \mathrm{C}$ and kept at this temperature for half an hour. To compare obtained results with other cellulose-based materials which are synthesized by our group, the annealing time is the same as in our previously published articles (Jankowska et al. 2018, 2020; Smolarkiewicz et al. 2015, 2016). Next, the materials were cooled down to $10{ }^{\circ} \mathrm{C}$ and then heating up to $250{ }^{\circ} \mathrm{C}$.

The proton conductivity of measured samples was characterized by means of impedance spectroscopy (an Alpha-A high-performance analyzer, Novocontrol $\mathrm{GmbH}$; a Quatro Cryosystem, accuracy better than $\pm 0.01{ }^{\circ} \mathrm{C}$; the frequency range $1 \mathrm{~Hz}-10 \mathrm{MHz}$; the voltage oscillations of $\pm 1 \mathrm{~V}$ ). The film samples were covered with Hans Wolbring GmbH silver paste. The samples had $2.8 \mathrm{~mm}$ in diameter and $0.3 \mathrm{~mm}$ in thickness for CNF, and $0.4 \mathrm{~mm}$ in thickness for $2 \mathrm{CNF}$ Im sample. The complex impedance of the materials was measured using two measurement procedures. The first one included the following cycles: the first heating cycle from 0 to $110{ }^{\circ} \mathrm{C}$, kept at this temperature for $0.5 \mathrm{~h}$, and cooled to $0{ }^{\circ} \mathrm{C}$; next, the conductivity of CNF and 2CNF-Im composite was studied up to $230{ }^{\circ} \mathrm{C}$, and $200{ }^{\circ} \mathrm{C}$, respectively. During the second procedure, the complex impedance measurement of 2CNF-Im was carried out in four heating steps: the first one from 0 to $110^{\circ} \mathrm{C}$, and the second, third and fourth heating cycles: from 0 to $130{ }^{\circ} \mathrm{C}$.

\section{Results and discussion}

The composition of 2CNF-Im was calculated based on the results of elemental analysis. The average percentage of nitrogen, carbon, and hydrogen atoms is equal to $6.87 \%, 43.53 \%$, and $6.34 \%$, respectively. According to these results, the 2CNF-Im nanocomposite contains one imidazole molecule per 2 glucose units. The CNF average percentage of hydrogen and carbon atoms equals $6.62 \%$ and $43.48 \%$, respectively. In both samples, no sulfur or chlorine atoms were detected.

Figure 2a, b depicts the morphology of CNF and 2CNF-Im films. As a result of hydrogel drying and water evaporation, individual nanofibers join into larger structures and form bundles. SEM images show a network structure consisting of random assembly of nanofibers and bundles (Fig. 2c, d). The nominal individual nanofiber width is equal to $50 \mathrm{~nm}$, and length is up to approximately $220 \mu \mathrm{m}$. A few individual nanofibers are shown in Fig. 2e, f. The pure cellulose nanofiber-based matrix and nanocomposite images do not differ, no imidazole crystallites are observed on the nanocellulose matrix surface.

Figure 3 shows the results of TGA and the corresponding derivative of TGA (DTG) for CNF and 2CNF-Im samples. Detailed information on the weight loss $(\Delta Y)$ and temperatures (the onset, endset, and maximum temperature of degradation processes $-T_{0}$ ) are provided in Table 1. One can observe a characteristic initial mass loss (I) on TGA curves for both studied materials, associated with evaporation of 

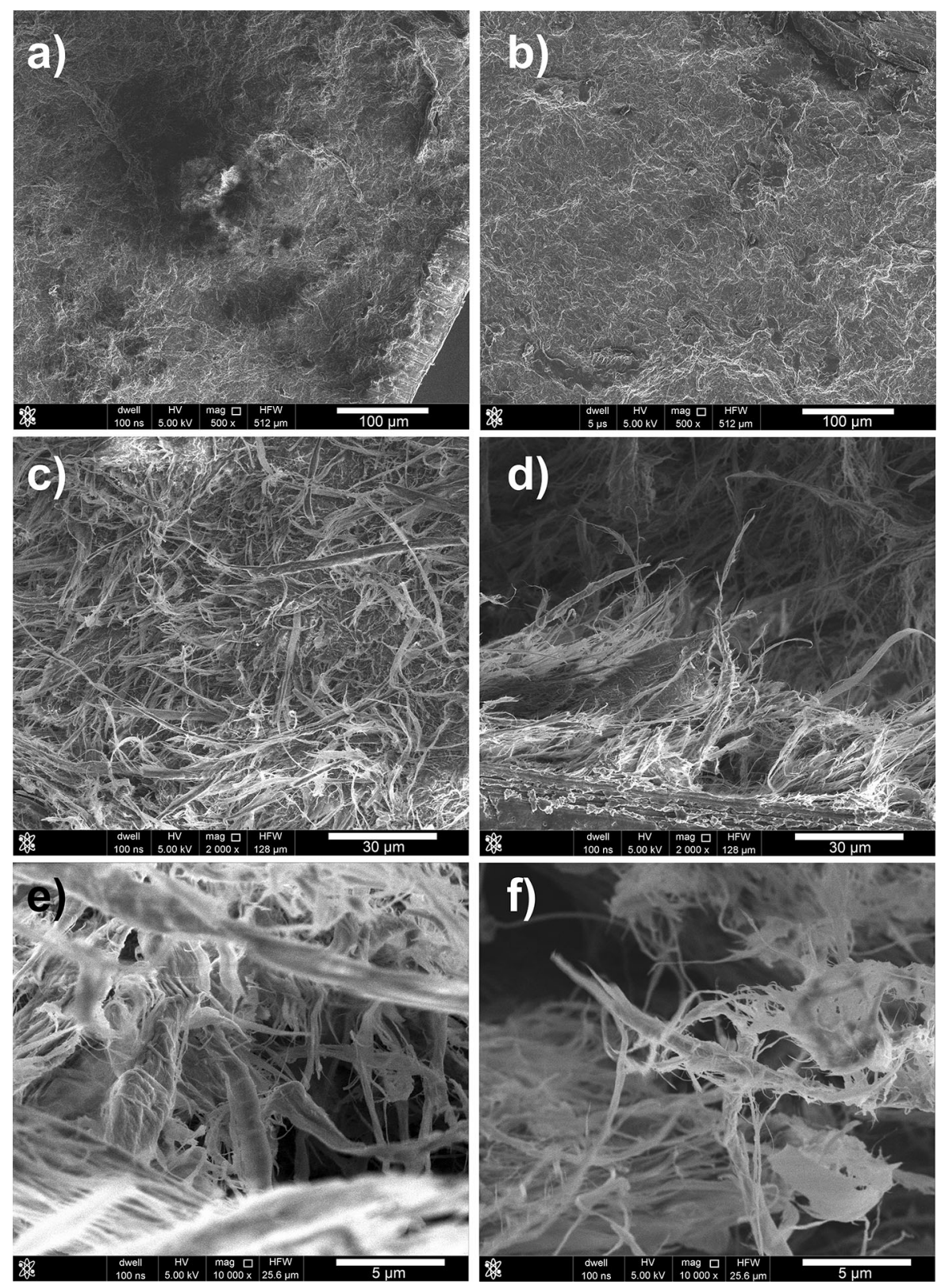

Fig. 2 SEM images: the morphology of surfaces CNF matrix (a) and 2CNF-Im nanocomposite (b); the nanofibers bundle CNF bundle with visible single nanofibers for the CNF matrix (e) and the 2CNF-Im nanocomposite (f) random network structure of $\mathrm{CNF}$ (c) and 2CNF-Im (d); the

water. Then, decomposition of the film material (a small mass loss step about $250{ }^{\circ} \mathrm{C}$ ) and a large weight loss connected with cellulose pyrolysis are observed for both samples (II) (Jankowska et al. 2018; Tao et al. 2019; Zhang et al. 2018, 2019). For the nanocomposite sample, the mass loss due to its decomposition is greater, which is also visible on the derivative curve.

Higher thermal stability of pure CNF has already been found in comparison to other cellulose materials in the nanoscale (Jankowska et al. 2018). A similar situation is observed for the CNF-based nanocomposite. For a similar content of imidazole (1.7) in a nanocomposite based on CNC (Tritt-Goc et al. 2018), the first significant decay after evaporation of water, 


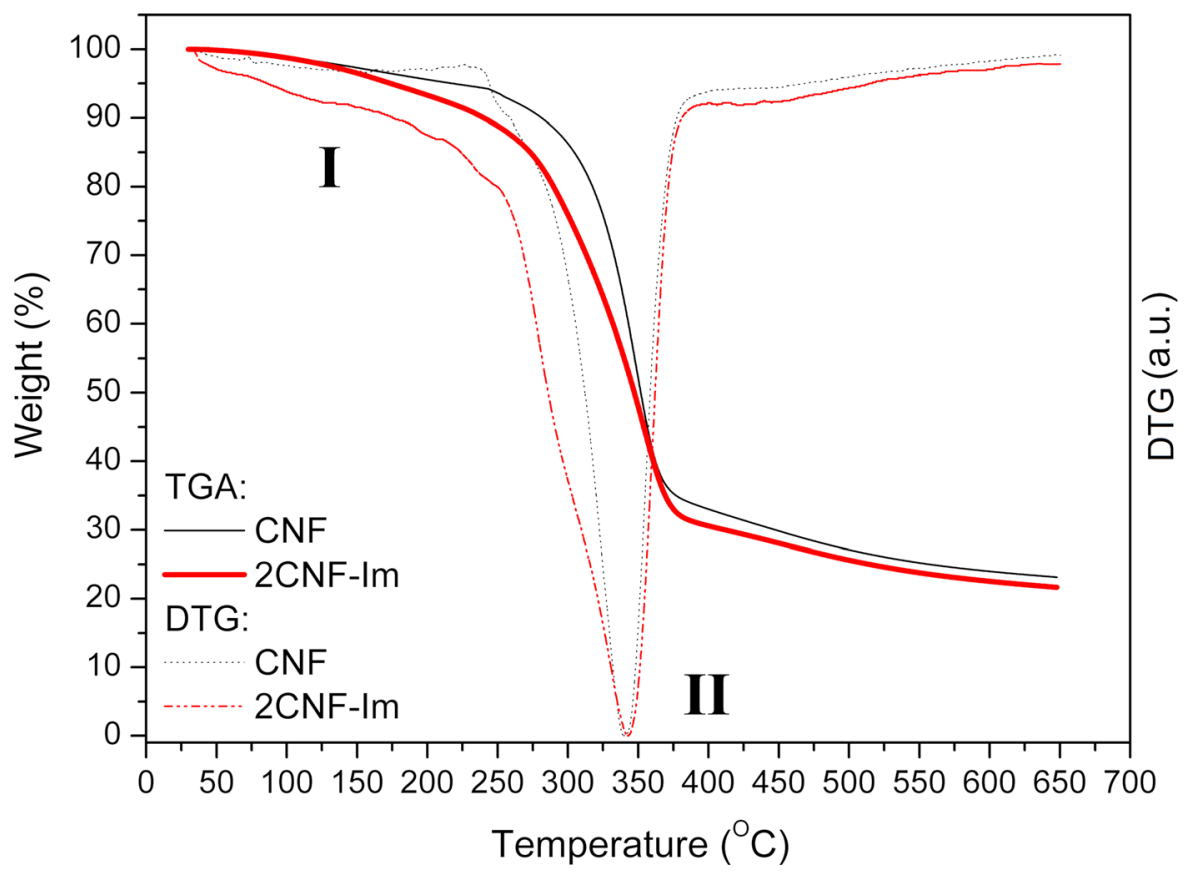

Fig. 3 Comparison of TGA thermograms and the corresponding derivatives curves for CNF and 2CNF-Im films

Table 1 The weight loss $(\Delta Y)$, onset, endset, and maximum temperature $\left(T_{0}\right)$ of decomposition processes for $\mathrm{CNF}$ and 2CNF-Im films

\begin{tabular}{lrrrrr}
\hline & \multicolumn{2}{l}{$\mathrm{CNF}$} & & \multicolumn{2}{l}{ 2CNF-Im } \\
\cline { 2 - 3 } \cline { 6 - 7 } & \multicolumn{1}{l}{ I } & \multicolumn{1}{c}{ II } & & I & \multicolumn{1}{c}{ II } \\
\hline$\Delta Y(\%)$ & 6.70 & 60.23 & & 13.59 & 56.38 \\
Onset $\left({ }^{\circ} \mathrm{C}\right)$ & 85.71 & 293.23 & & 37.42 & 274.33 \\
Endset $\left({ }^{\circ} \mathrm{C}\right)$ & 168.74 & 369.00 & & 188.69 & 371.72 \\
$T_{O}\left({ }^{\circ} \mathrm{C}\right)$ & 157.74 & 339.83 & & 161.43 & 342.59 \\
\hline
\end{tabular}

associated with the decomposition of the nanocomposite, is observed at $\mathrm{T}_{0}=150{ }^{\circ} \mathrm{C}$. In addition, for the nanocomposites based on $\mathrm{CNC}$, a characteristic decomposition process with $\mathrm{T}_{0}$ of about $225^{\circ} \mathrm{C}$ is visible. The mass loss observed for the $2 \mathrm{CNF}-\mathrm{Im}$ nanocomposite is smaller than the sum of the mass losses for the decomposition processes in a CNCbased nanocomposite with a similar imidazole content in the temperature range below the pyrolysis process. For 2CNF-Im only a wide peak associated with water evaporation, and a slight loss of imidazole (without a clear peak connected with this process) is observed on the DTG curve. Moreover, the broadening of the peak assigned to cellulose pyrolysis on DTG is noticeable, which is associated with degradation of the composite at higher temperatures than that needed for degradation of nanocrystalline composites (Tritt-Goc et al. 2018). The nanocomposite based on CNF is more thermally stable. Furthermore, for the composite based on CMF or CNC nanocomposites, after evaporation of water, a weight loss stage was observed associated with the loss of imidazole from the sample (at $155^{\circ} \mathrm{C}$ ) (Jankowska et al. 2020). This step is not observed for the nanofibers composite, which shows that the thermal stability of the CNF composite is higher than that of the previously studied composites based on other cellulose materials.

The DSC results obtained during the first heating cycles up to $110{ }^{\circ} \mathrm{C}$ and the second heating cycles up to $250{ }^{\circ} \mathrm{C}$ for $\mathrm{CNF}$ and $2 \mathrm{CNF}-\mathrm{Im}$ nanocomposite samples are shown in Fig. 4. In the first heating cycle, small broad endothermic peaks associated with the evaporation of weakly bonded water and moisture from the surface of the films, are seen. The peaks for $\mathrm{CNF}$ and 2CNF-Im samples have a maximum at $55^{\circ} \mathrm{C}$ and $59^{\circ} \mathrm{C}$, respectively. The enthalpy of the process is equal to $0.3 \mathrm{~J} / \mathrm{g}$ for CNF sample and $1.6 \mathrm{~J} / \mathrm{g}$ for $2 \mathrm{CNF}$ Im sample. Above $80{ }^{\circ} \mathrm{C}$ for the pure CNF film the evaporation of strongly bonded water from the 


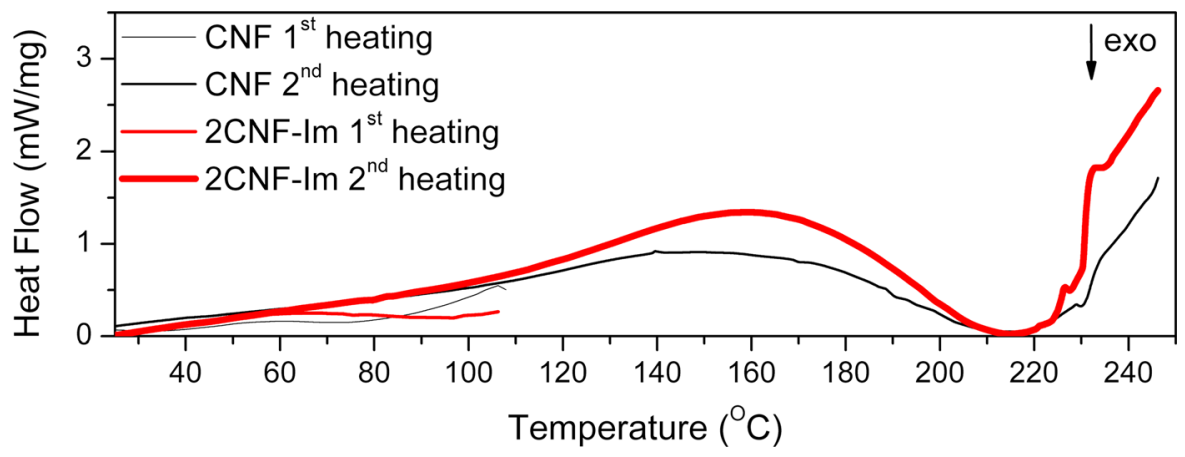

Fig. 4 DSC curves obtained during the first and the second heating cycles for CNF and 2CNF-Im

material begins. During the second heating cycle, wide endothermic peaks are visible for both samples. These peaks correspond to the process of evaporation of strongly bonded water. The peak has the temperature maximum at $150{ }^{\circ} \mathrm{C}$ for $\mathrm{CNF}$ sample, and $160{ }^{\circ} \mathrm{C}$ for 2CNF-Im sample. These processes are characterized by the enthalpy of $20.3 \mathrm{~J} / \mathrm{g}$ for CNF sample and $33.1 \mathrm{~J} /$ $\mathrm{g}$ for 2CNF-Im sample. For the nanocomposite, the higher temperature maximum and enthalpy of the process indicate the beginning of 2CNF-Im decomposition consisting of breaking hydrogen bonds between the cellulose matrix and imidazole. For both materials, the decomposition of polymer films begins above $220^{\circ} \mathrm{C}$. For the nanocomposites based on $\mathrm{CNC}$, the process of film degradation began above $180{ }^{\circ} \mathrm{C}$ (Tritt-Goc et al. 2018).

The electrical conductivity of the new nanomaterial was studied by the impedance spectroscopy. Selected impedance spectra of both samples recorded in the frequency window from $1 \mathrm{~Hz}$ to $10 \mathrm{MHz}$ are shown in Fig. 5. The response of the studied materials can be estimated as one semicircle. The experimental data were analyzed using the Cole equation:

$Z^{*}(\omega)=Z^{\prime}(\omega)+i Z^{\prime \prime}(\omega)=\frac{R_{D C}}{1+(i \omega \tau)^{\alpha}}$

where $Z^{*}(\omega)$ - the complex impedance at angular frequency $\omega(\omega=2 \pi f$; $f$ - the linear frequency of the probing electric field), $Z^{\prime}(\omega)$ and $Z^{\prime \prime}(\omega)$ - the real and imaginary components of complex impedance, respectively, $R_{D C}$ - the direct current resistance, $\tau=2 \pi R C$ - a characteristic time constant ( $C$ - capacity), $\alpha$-an empirical exponent, $0<\alpha \leq 1$. In Fig. 5 the solid lines show the best fit of Eq. 1 to the experimental points. Knowing the sample dimensions, the bulk direct current conductivity, $\sigma_{\mathrm{DC}}$, can be calculated from the formula $\sigma_{D C}=1 / R_{D C}(d / A)$, where $d$ - the sample thickness, $A$ - the sample surface area.

A comparison of conductivity values for pure cellulose nanofiber-based matrix and 2CNF-Im nanocomposites as a function of reciprocal temperature is presented in Fig. 6. The differences in conductivity between the first and second heating cycles are due to the presence of weakly bonded water during the first heating cycles in both materials. After evaporation of weakly bonded water, the points corresponding to the conductivity values for cooling and the second heating cycles coincide, and the materials are electrically stable. The insert in Fig. 6 presents the results of the second measurement of 2CNF-Im for the second, third and fourth heating cycles in the temperature range $80-130{ }^{\circ} \mathrm{C}$. Figure 7 depicts Nyquist plots and frequency alternating conductivity, $\sigma_{\mathrm{AC}}$, dependencies for the 2CNF-Im nanocomposite measured during the first heating, cooling, and second heating cycle at $100{ }^{\circ} \mathrm{C}$. The results are almost the same. The conductivity values for the second, third and fourth heating cycles are the same (see the insert in Fig. 6), and the results show high electrical stability of 2CNF-Im nanocomposite. Thanks to the use of $\mathrm{CNF}$, it was possible to obtain the first electrically stable composite based on a pure cellulose polymer matrix functionalized with imidazole. Previously synthesized composites based on other cellulose materials did not exhibit these properties (Jankowska et al. 2020; Smolarkiewicz et al. 2015; Tritt-Goc et al. 2018).

The maximum conductivity value for $2 \mathrm{CNF}-\mathrm{Im}$ nanocomposite is four orders of magnitude higher than that of CNF cellulose matrix, $7.0 \times 10^{-3} \mathrm{~S} / \mathrm{m}$ and $1.3 \times 10^{-7} \mathrm{~S} / \mathrm{m}$ at $140{ }^{\circ} \mathrm{C}$, respectively. $2 \mathrm{CNF}-\mathrm{Im}$ nanocomposite shows the maximum electrical 


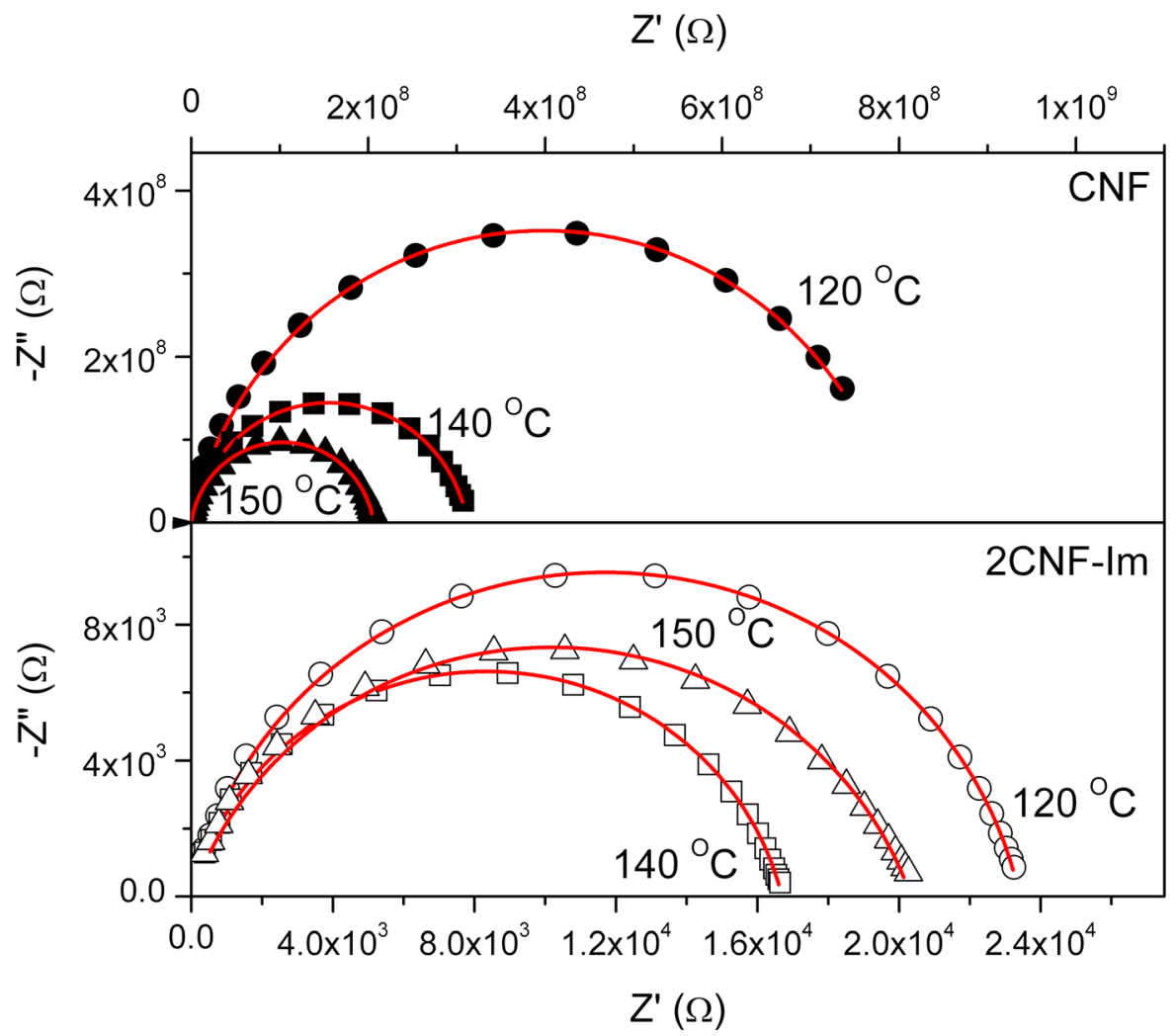

Fig. 5 Nyquist plots for CNF and 2CNF-Im at 120, 140 and $150{ }^{\circ} \mathrm{C}$. The most significant are differences in values of impedance for both samples ( $\mathrm{Z}^{\prime}$ scale up to $1.1 \times 10^{9} \Omega$ for CNF sample, while for $2 \mathrm{CNF}-\mathrm{Im}$ sample up to $2.7 \times 10^{4} \Omega$ )

conductivity in anhydrous conditions at temperatures higher than the boiling point of water. The electrical conductivity of 2CNF-Im is related to the presence of imidazole molecules in the cellulose nanofiber-based matrix.

The activation energies of proton transport were determined for both samples from the Arrhenius law:

$\sigma(T)=\sigma_{0} \exp \left(-E_{a} / k T\right)$

where $E_{a}$ - the activation energy, $\sigma_{0}$-the pre-exponential factor, $T$-temperature, and $k$-the Boltzmann constant. The best-fit curves are presented in Fig. 6 (solid lines). The estimated error is $\pm 0.01 \mathrm{eV}$. For pure CNF cellulose matrix the activation energy equals $0.75 \mathrm{eV}$, while for the nanocomposite 2CNFIm: $E_{a}=0.62 \mathrm{eV}$. In comparison with the activation energies for membranes of fully swollen Nafion $(0.16 \mathrm{eV})$ and cellulose nanomaterials in the hydrated state ( $\sim 0.20 \mathrm{eV})$ (Bayer et al. 2016; Liu et al. 2018), the $E_{a}$ of 2CNF-Im is higher. The value of the activation energy of pure CNF $(0.75 \mathrm{eV})$ is lower compared to those of the other pure cellulose materials (for example, for the CNC film it is equal to $1.07 \mathrm{eV}$, for CMF it is $1.2 \mathrm{eV}$ ) (Jankowska et al. 2018, 2020). For 2CNF-Im nanocomposite, the activation energy $(0.62 \mathrm{eV})$ is the lowest from among the values for the other composites based on pure cellulose: in 5.4CMC$\mathrm{Im}$, the activation energy is $0.82 \mathrm{eV}$; 3.5CMF-Im$0.95 \mathrm{eV} ; 1.3 \mathrm{CNC}-\mathrm{Im}-0.78 \mathrm{eV}$ (Jankowska et al. 2020; Smolarkiewicz et al. 2015, 2016; Tritt-Goc et al. 2019).

\section{Conclusions}

The first attempt to obtain the new liquid-free polymeric nanocomposite in the form of the film, based on pure CNF matrix functionalized with imidazole, was successful. The new nanomaterial, $2 \mathrm{CNF}-$ $\mathrm{Im}$, exhibits proton conductivity above the boiling point of water, with the maximum at $140{ }^{\circ} \mathrm{C}$ equals $7.0 \times 10^{-3} \mathrm{~S} / \mathrm{m}$. For the pure CNF matrix at the same 


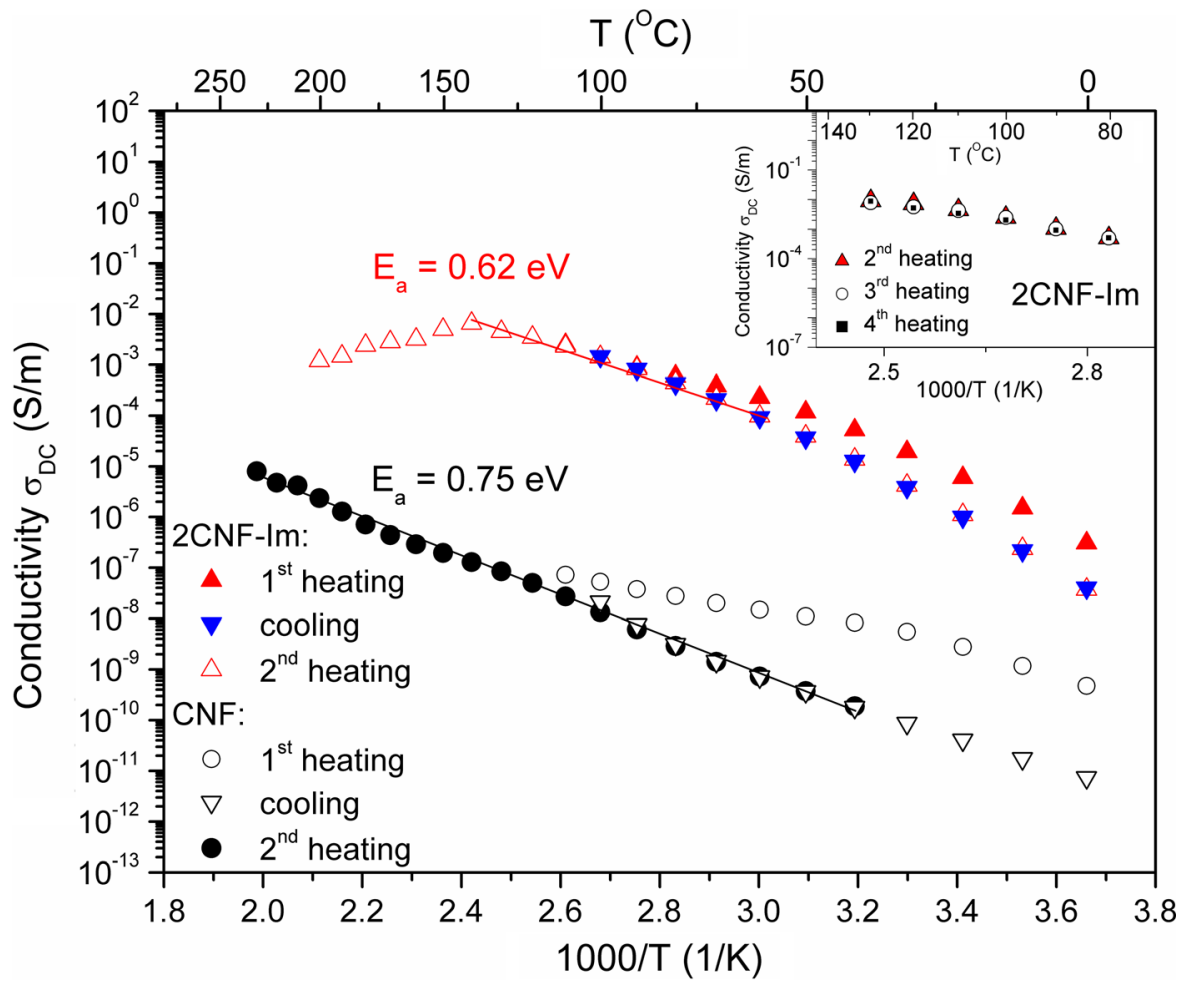

Fig. 6 Arrhenius plots and the activation energies of proton conductivity for CNF and 2CNF-Im. The insert shows a comparison of the conductivity values for $2 \mathrm{CNF}-\mathrm{Im}$ measured during the second, third and fourth heating cycles in the temperature range $80-130{ }^{\circ} \mathrm{C}$

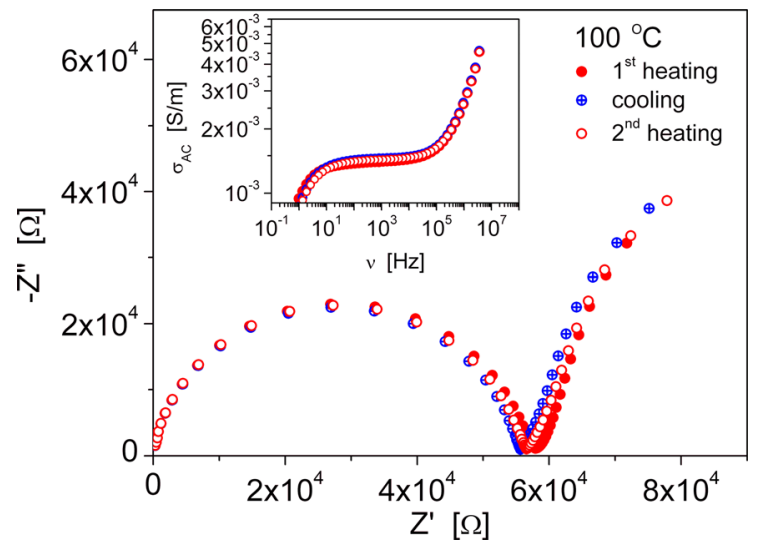

Fig. 7 Impedance spectra and alternating conductivity $\sigma_{\mathrm{AC}}$ as a function of frequency (inset) for the 2CNF-Im nanocomposite at $100{ }^{\circ} \mathrm{C}$

temperature, the conductivity value is equal to $1.3 \times 10^{-7} \mathrm{~S} / \mathrm{m}$. The difference between the ionic conductivity values of CNF and 2CNF-Im is four orders of magnitude. Such a significant change in material properties allows concluding that the cellulose nanofiber-based matrix has successfully functionalized with imidazole molecules. The new 2CNF-Im nanocomposite shows higher thermal end electrical stability than that of previously synthesized liquid-free composites based on pure micro and nano cellulose materials (Jankowska et al. 2020; Smolarkiewicz et al. 2015, 2016; Tritt-Goc et al. 2018, 2019). Moreover, the activation energy of the proton transport process $\left(E_{a}=0.62 \mathrm{eV}\right)$ in 2CNF-Im is the lowest when compared to those of the previously synthesized pure cellulose-based composites exhibit proton conductivity above $100{ }^{\circ} \mathrm{C}$ : CMC-based composite $(0.82 \mathrm{eV})$, CMF-based $(0.95 \mathrm{eV})$, and CNCbased composite $(0.78 \mathrm{eV})$ (Jankowska et al. 2020; Smolarkiewicz et al. 2015, 2016; Tritt-Goc et al. 2019). Due to the use of CNF to synthesize of the composite, the imidazole concentration is increasing in comparison to cellulose microfiber-based composite: in CNF-based composite-one imidazole molecule per 2 glucose units, and CMF-based compositeone imidazole molecule per 3.5 glucose units (Jankowska et al. 2020). The mechanical obtained pure $\mathrm{CNF}$ as a product of naturally occurring cellulose 
are a renewable, low-cost and eco-friendly resource (Lee et al. 2014). Further modifications of pure CNF with heterocyclic compounds may result in the formation of eco-friendly, low-cost, solid-state polymer electrolytes that can be used above $100{ }^{\circ} \mathrm{C}$. In the future, these materials can be an interesting replacement for currently used electrolytes working in hydration conditions.

Acknowledgments The authors would like to thank Prof. J. Tritt-Goc, from the Institute of Molecular Physics, Polish Academy of Sciences in Poznań, for discussions that improved the manuscript.

Funding Funding for the present work was provided by the National Science Centre, Poland [grant number 2017/24/C/ST5/ 00156].

\section{Compliance with ethical standards}

Conflict of interest The authors declare that they have no conflict of interest.

Open Access This article is licensed under a Creative Commons Attribution 4.0 International License, which permits use, sharing, adaptation, distribution and reproduction in any medium or format, as long as you give appropriate credit to the original author(s) and the source, provide a link to the Creative Commons licence, and indicate if changes were made. The images or other third party material in this article are included in the article's Creative Commons licence, unless indicated otherwise in a credit line to the material. If material is not included in the article's Creative Commons licence and your intended use is not permitted by statutory regulation or exceeds the permitted use, you will need to obtain permission directly from the copyright holder. To view a copy of this licence, visit http://creativecommons.org/licenses/by/4.0/.

\section{References}

Bano S, Negi Y, Illathvalappil R, Kurungot S, Ramya K (2019) Studies on nano composites of SPEEK/ethylene glycol/cellulose nanocrystals as promising proton exchange membranes. Electrochim Acta 293:260-272. https://doi. org/10.1016/j.electacta.2018.10.029

Bayer T, Cunning BV, Selyanchyn R, Nishihara M, Fujikawa S, Sasaki K, Lyth SM (2016) High temperature proton conduction in nanocellulose membranes: paper fuel cells. Chem Mater 28:4805-4814. https://doi.org/10.1021/acs. chemmater.6b01990

Bhatnagar A, Sharma PK, Kumar N (2011) A review on "imidazoles": their chemistry and pharmacological potentials. Int J PharmTech Res 3:268-282

Cai Z, Li R, Xu X, Sun G, Zhuang X, Liu Y, Cheng B (2018) Embedding phosphoric acid-doped cellulose nanofibers into sulfonated poly(ether sulfone) for proton exchange membrane. Polymer 156:179-185. https://doi.org/10.1016/ j.polymer.2018.10.013

Di Y, Yin X (2019) Reinforced proton conductivity through imidazole-loaded cellulose nanofibers for proton exchange membranes. Mater Res Express 6:116403. https://doi.org/ 10.1088/2053-1591/ab4384

Fujishima M, Matsuo Y, Takatori H, Uchida K (2008) Protonconductive acid-base complex consisting of $\mathrm{j}$-carrageenan and 2-mercaptoimidazole. Electrochem Commun 10:1482-1485. https://doi.org/10.1016/j.elecom.2008.07. 040

Gadim TDO, Vilela C, Loureiro FJA, Silvestre AJD, Freire CSR, Figueiredo FML (2016) Nafion and nanocellulose: a partnership for greener polymer electrolyte membranes. Ind Crop Prod 93:212-218. https://doi.org/10.1016/j. indcrop.2016.01.028

Gu X, Li B, Li F, Zhang K, Guo M (2019) Transparent and flexible vermiculite-cellulose nanofiber composite membranes with high-temperature proton conduction. J Mater Sci 54:5528-5535. https://doi.org/10.1007/s10853-01803269-8

Guccini V, Carlson A, Yu S, Lindbergh G, Lindstrom RW, Salazar-Alvarez G (2019) Highly proton conductive membranes based on carboxylated cellulose nanofibres and their performance in proton exchange membrane fuel cells. J Mater Chem A 7:25032. https://doi.org/10.1039/ c9ta04898g

Hernández-Flores G, Poggi-Varaldo HM, Solorza-Feria O (2016) Comparison of alternative membranes to replace high cost Nafion ones in microbial fuel cells. Int J Hydrog Energy 41:23354-23362. https://doi.org/10.1016/j. ijhydene.2016.08.206

Jankowska I, Pankiewicz R, Pogorzelec-Glaser K, Ławniczak P, Łapiński A, Tritt-Goc J (2018) Comparison of structural, thermal and proton conductivity properties of micro- and nanocelluloses. Carbohydr Polym 200:536-542. https:// doi.org/10.1016/j.carbpol.2018.08.033

Jankowska I, Ławniczak P, Pogorzelec-Glaser K, Łapiński A, Pankiewicz R, Tritt-Goc J (2020) Cellulose microfibers surface treated with imidazole as new proton conductors. Mater Chem Phys 239:122056. https://doi.org/10.1016/j. matchemphys.2019.122056

Jesuraj K, Manimuthu RP (2018) Preparation and characterization of hybrid chitosan/PEO-silica membrane doped with phosphotungstic acid for PEM fuel cell application. Polym Plast Technol 58:14-30. https://doi.org/10.1080/ 03602559.2018.1455862

Jiang G, Qiao J, Hong F (2012) Application of phosphoric acid and phytic acid-doped bacterial cellulose as novel protonconducting membranes to PEMFC. Int J Hydrog Energy 37:9182-9192. https://doi.org/10.1016/j.ijhydene.2012.02. 195

Kalaiselvimary J, Prabhu MR (2018) Influence of sulfonated $\mathrm{GO} /$ sulfonated biopolymer as polymer electrolyte membrane for fuel cell application. J Mater Sci Mater Electron 29:5525-5535. https://doi.org/10.1007/s10854-018-85216

Kalaiselvimary J, Selvakumar K, Rajendran S, Sowmya G, Prabhu MR (2019) Effect of surface-modified montmorillonite incorporated biopolymer membranes for PEM fuel 
cell applications. Polym Compos 40:E301-E311. https:// doi.org/10.1002/pc.24655

Lee HV, Hamid SBA, Zain SK (2014) Conversion of lignocellulosic biomass to nanocellulose: structure and chemical process. Sci World J 2014:631013. https://doi.org/10.1155/ 2014/631013

Liu L, Chen W, Li Y (2018) A statistical study of proton conduction in Nafion ${ }^{\circledR}$-based composite membranes: prediction, filler selection and fabrication methods. J Membr Sci 549:393-402. https://doi.org/10.1016/j.memsci.2017.12. 025

Mizera A, Grabowski SJ, Ławniczak P, Wysocka-Żołopa M, Dubis AT, Łapiński A (2019) A study of the optical, electrical and structural properties of poly(pyrrole-3,4-dicarboxylic acid). Polymer 164:142-153. https://doi.org/10. 1016/j.polymer.2018.12.056

Ni C, Wei Y, Hu Q, Li X, Liu B, Zhao Q, Zhang M, Li Y, Hu W (2016) Nanocystalline cellulose reinforced sulfonated fluorenyl-containing polyaryletherketones for proton exchange membranes. Solid State Ionics 297:29-35. https://doi.org/10.1016/j.ssi.2016.09.027

Ni C, Wei Y, Zhao Q, Liu B, Sun Z, Gu Y, Zhang M, Hua W (2018) Novel proton exchange membranes based on structure-optimized poly(ether ether ketone ketone)s and nanocrystalline cellulose. Appl Surf Sci 434:163-175. https://doi.org/10.1016/j.apsusc.2017.09.094

Połomska M, Pogorzelec-Glaser K, Pawlaczyk C (2010) FTNIR Raman and proton conductivity studies of new polymer composite: alginic acid-heterocyclic molecules. Phase Transit 83:844-853. https://doi.org/10.1080/01411594. 2010.509154

Połomska M, Pogorzelec-Glaser K, Pawlaczyk C, Pietraszko A (2011) FT NIR Raman studies of alginic acid-benzimidazole polymer composite. Spectrochim Acta A 79:797-800. https://doi.org/10.1016/j.saa.2010.08.055

Smolarkiewicz I, Rachocki A, Pogorzelec-Glaser K, Pankiewicz R, Ławniczak P, Łapiński A, Jarek M, Tritt-Goc J (2015) Proton-conducting microcrystalline cellulose doped with imidazole. Thermal and electrical properties. Electrochim Acta 155:38-44. https://doi.org/10.1016/j. electacta.2014.11.205

Smolarkiewicz I, Rachocki A, Pogorzelec-Glaser K, Ławniczak P, Pankiewicz R, Tritt-Goc J (2016) Effect of surface coating of microcrystalline cellulose by imidazole molecules on proton conductivity. Eur Polym J 78:186-194. https://doi.org/10.1016/j.eurpolymj.2016.03.026

Sofla MRK, Brown RJ, Tsuzuki T, Rainey TJ (2016) A comparison of cellulose nanocrystals and cellulose nanofibres extracted from bagasse using acid and ball milling methods. Adv Nat Sci Nanosci Nanotechnol 7:035004-035013. https://doi.org/10.1088/2043-6262/7/3/035004

Sulaiman S, Mokhtar MN, Naim MN, Baharuddin AS, Sulaiman A (2015) A review: Potential usage of cellulose nanofibers (CNF) for enzyme immobilization via covalent interactions. Appl Biochem Biotechnol 175:1817-1842. https:// doi.org/10.1007/s12010-014-1417-X

Tao P, Wu Z, Xing C, Zhang Q, Wei Z, Nie S (2019) Effect of enzymatic treatment on the thermal stability of cellulose nanofibrils. Cellulose 26:7717-7725. https://doi.org/10. 1007/s10570-019-02634-3
Tiwari BR, Noori MT, Ghangrekar MM (2016) A novel low cost polyvinyl alcohol-Nafion-borosilicate membrane separator for microbial fuel cell. Mater Chem Phys 182:86-93. https://doi.org/10.1016/j.matchemphys.2016.07.008

Tritt-Goc J, Jankowska I, Pogorzelec-Glaser K, Pankiewicz R, Ławniczak P (2018) Imidazole-doped nanocrystalline cellulose solid proton conductor: synthesis, thermal properties, and conductivity. Cellulose 25:281-291. https://doi. org/10.1007/s10570-017-1555-8

Tritt-Goc J, Lindner Ł, Bielejewski M, Markiewicz E, Pankiewicz R (2019) Proton conductivity and proton dynamics in nanocrystalline cellulose functionalized with imidazole. Carbohydr Polym 225:115196. https://doi.org/10.1016/j. carbpol.2019.115196

Vilela C, Silva ACQ, Domingues EM, Gonçalves G, Martins MA, Figueiredo FML, Santosa SAO, Freire CSR (2020) Conductive polysaccharides-based proton-exchange membranes for fuel cell applications: the case of bacterial cellulose and fucoidan. Carbohydr Polym 230:115604. https://doi.org/10.1016/j.carbpol.2019.115604

Widelicka M, Pogorzelec-Glaser K, Pietraszko A, Ławniczak P, Pankiewicz R, Łapiński A (2017) Order-disorder phase transition in an anhydrous pyrazole-based proton conductor: the enhancement of electrical transport properties. Phys Chem Chem Phys 19:25653-25661. https://doi.org/ 10.1039/C7CP05708C

Wong CY, Wong WY, Ramya K, Khalid M, Loh KS, Daud WRW, Lim KL, Walvekar R, Kadhum AAH (2019) Additives in proton exchange membranes for low- and high-temperature fuel cell applications: a review. Int $\mathrm{J}$ Hydrog Energy 44:6116-6135. https://doi.org/10.1016/j. ijhydene.2019.01.084

Xu X, Liu F, Jiang L, Zhu JY, Haagenson D, Wiesenborn DP (2013) Cellulose nanocrystals vs. cellulose nanofibrils: a comparative study on their microstructures and effects as polymer reinforcing, agents. ACS Appl Mater Interfaces 5:2999-3009. https://doi.org/10.1021/am302624t

Xu X, Li R, Tang C, Wang H, Zhuang X, Liu Y, Kang W, Shi L (2018) Cellulose nanofiber-embedded sulfonated poly (ether sulfone) membranes for proton exchange membrane fuel cells. Carbohydr Polym 184:299-306. https://doi.org/ 10.1016/j.carbpol.2017.12.074

Xu X, Zhao G, Wang X, Li X, Feng X, Cheng B, Shi L, Kang W, Zhuang X, Yin Y (2019) Bio-inspired amino-acid-functionalized cellulose whiskers incorporated into sulfonated polysulfone for proton exchange membrane. J Power Sources 409:123-131. https://doi.org/10.1016/j.jpowsour. 2018.11.003

Yamada M, Goto A (2012) Proton conduction of DNA-imidazole composite material under anhydrous condition. Polym J 44:415-420. https://doi.org/10.1038/pj.2012.5

Yamada M, Ogino T (2015) Anhydrous proton conductor consisting of pectin-inorganic composite material. J Appl Polym Sci 132:1-7. https://doi.org/10.1002/app.42433

Zhang K, Zhang Y, Yan D, Zhang C, Nie S (2018) Enzymeassisted mechanical production of cellulose nanofibrils: thermal stability. Cellulose 25:5049-5061. https://doi.org/ 10.1007/s10570-018-1928-7

Zhang N, Tao P, Lu Y, Nie S (2019) Effect of lignin on the thermal stability of cellulose nanofibrils produced from 
bagasse pulp. Cellulose 26:7823-7835. https://doi.org/10. 1007/s10570-019-02657-w

Zhao L, Smolarkiewicz I, Limbach HH, Breitzke H, PogorzelecGlaser K, Pankiewicz R, Tritt-Goc J, Gutmann T, Buntkowsky $G$ (2016) Imidazole-doped cellulose as membrane for fuel cells: structural and dynamic insights from solidstate NMR. J Phys Chem C 120:19574-19585. https://doi. org/10.1021/acs.jpcc.6b07049

Zhao Q, Wei Y, Ni C, Wang L, Liu B, Liu J, Zhang M, Men Y, Sun Z, Xie H, Hu W, Lug Y (2019a) Effect of aminated nanocrystal cellulose on proton conductivity and dimensional stability of proton exchange membranes. Appl Surf Sci 466:691-702. https://doi.org/10.1016/j.apsusc.2018. 10.063
Zhao G, Xu X, Di Y, Wang H, Cheng B, Shi L, Zhu Y, Zhuang X, Yin Y (2019b) Amino acid clusters supported by cellulose nanofibers for proton exchange membranes. J Power Sources 438:227035. https://doi.org/10.1016/j.jpowsour. 2019.227035

Zięba S, Dubis A, Ławniczak P, Gzella A, Pogorzelec-Glaser K, Łapinski A (2019) Effect of counter ions on physical properties of imidazole-based proton conductors. Electrochim Acta 306:575-589. https://doi.org/10.1016/j. electacta.2019.03.125

Publisher's Note Springer Nature remains neutral with regard to jurisdictional claims in published maps and institutional affiliations. 